\title{
Effect of sire breed on intake of grazing beef steers
}

\author{
EE Grings 1, RE Short 1, DC Adams 2 \\ IUSDA-ARS, Ft Keogh LARRL, Miles City, MT 59301; 2West Central Research and Education \\ Center, University of Nebraska-Lincoln, North Platte, NB, USA
}

A 3-year study was conducted to monitor the effects of sire breed of steers on food intake. Steers sired by high (Charolais) or moderate (Hereford) growth potential bulls were grazed near Miles City, MT $\left(46^{\circ} 22^{\prime} \mathrm{N}, 105^{\circ} 5^{\prime} \mathrm{W}\right)$. Fecal output of suckling calves and yearling steers was estimated using chromic sesquioxide in a sustained release bolus (Captec, Nufarm) as an external marker. In vitro digestibility of esophageal masticate was used to determine diet digestibility. Milk intake of calves was measured by weigh-suckleweigh. June collections were made on 68 ha of rangeland that had been seeded to Russian wildrye (Psathrostachys juncea). July collections were made on 80 ha of contour furrowed rangeland that was interseeded with alfalfa (Medicago sativa). September collections were made in a 265 ha pasture of native rangeland. Suckling calves were weaned in early October and placed on a 38ha irrigated pasture of a wheatgrass-wildrye complex. Forage intakes of these calves were measured in late October and early December.

Weight was greater $(P<0.01)$ for Charolais$(158 \mathrm{~kg})$ than Hereford-sired suckling calves
(136 kg). Milk organic matter intake tended to be greater $(P=0.06)$ for high $(453 \mathrm{~g} / \mathrm{d})$ than moderate growth potential calves $(418 \mathrm{~g} / \mathrm{d})$. However, forage $(1358 \mathrm{~g} / \mathrm{d})$ and total $(1795 \mathrm{~g} / \mathrm{d})$ intakes were not affected by sire breed.

After weaning, Charolais-sired steers gained faster $(0.69 \mathrm{~kg} / \mathrm{d})$ and ate more $(4.1 \mathrm{~kg} / \mathrm{d})$ compared to Hereford-sired steers $(0.55$ and $3.7 \mathrm{~kg} / \mathrm{d} ; \mathrm{P}<0.01)$.

Although Charolais-sired yearling steers $(345 \mathrm{~kg})$ were heavier than Hereford-sired steers $(315 \mathrm{~kg})$, there were no differences in intake, expressed as either $\mathrm{kg} / \mathrm{d}$ or a percentage of body weight. There was also no effect of sire breed on average daily gain.

Forage intake varied by year for all groups of steers. Forage intake was greatest in 1992 for both suckling calves and yearlings, but was lowest in 1992 during the fall postweaning period.

We conclude that sire breed effects on intake and growth were greatest during the postweaning period as compared to preweaning period and as yearlings.

\begin{tabular}{|c|c|c|c|c|c|c|c|}
\hline \multirow[t]{3}{*}{ Steer age } & \multirow[t]{3}{*}{ Sire breed } & \multicolumn{6}{|c|}{ Forage Intake } \\
\hline & & \multicolumn{3}{|c|}{$\mathrm{kg} / \mathrm{d}$} & \multicolumn{3}{|c|}{$\%$ of body weight } \\
\hline & & 1990 & 1991 & 1992 & 1990 & 1991 & 1992 \\
\hline \multirow[t]{2}{*}{ Suckling calf } & Charolais & 0.9 & 1.6 & 1.6 & 0.63 & 0.95 & 0.81 \\
\hline & Hereford & 1.0 & 1.3 & 1.6 & 0.72 & 0.83 & 0.97 \\
\hline \multirow[t]{2}{*}{ Postweaning } & Charolais & 4.4 & 4.8 & 3.8 & 1.94 & 1.76 & 1.56 \\
\hline & Hereford & 4.2 & 3.7 & 3.2 & 1.99 & 1.60 & 1.42 \\
\hline \multirow[t]{2}{*}{ Yearling } & Charolais & 5.3 & 5.0 & 6.9 & 1.25 & 1.29 & 1.62 \\
\hline & Hereford & 5.0 & 5.1 & 6.4 & 1.42 & 1.32 & 1.81 \\
\hline
\end{tabular}

